\title{
Downregulation of major histocompatibility complex antigens in invading glioma cells: stealth invasion of the brain
}

\author{
David Zagzag ${ }^{1,2,3,4,5}$, Konstantin Salnikow ${ }^{6}$, Luis Chiriboga ${ }^{2,5}$, Herman Yee ${ }^{2,5}$, Li Lan ${ }^{1,2}$, \\ M Aktar Ali ${ }^{1,2}$, Roberto Garcia ${ }^{2}$, Sandra Demaria ${ }^{2,5}$ and Elizabeth W Newcomb ${ }^{2,5}$
}

\begin{abstract}
${ }^{1}$ Microvascular and Molecular Neuro-oncology Laboratory, New York University School of Medicine, New York, NY, USA; ${ }^{2}$ Department of Pathology, New York University School of Medicine, New York, NY, USA; ${ }^{3}$ Division of Neuropathology, New York University School of Medicine, New York, NY, USA; ${ }^{4}$ Department of Neurosurgery, New York University School of Medicine, New York, NY, USA; ${ }^{5}$ New York University Cancer Institute, New York University School of Medicine, New York, NY, USA and ${ }^{6}$ National Cancer Institute, NIH,
\end{abstract} Frederick, MD, USA

\begin{abstract}
Invasion into surrounding brain tissue is a fundamental feature of gliomas and the major reason for treatment failure. The process of brain invasion in gliomas is not well understood. Differences in gene expression and/or gene products between invading and noninvading glioma cells may identify potential targets for new therapies. To look for genes associated with glioma invasion, we first employed Affymetrix microarray Genechip ${ }^{\mathbb{B}}$ technology to identify genes differentially expressed in migrating glioma cells in vitro and in invading glioma cells in vivo using laser capture microdissection. We observed upregulation of a variety of genes, previously reported to be linked to glioma cell migration and invasion. Remarkably, major histocompatiblity complex (MHC) class I and II genes were significantly downregulated in migrating cells in vitro and in invading cells in vivo. Decreased MHC expression was confirmed in migrating glioma cells in vitro using RT-PCR and in invading glioma cells in vivo by immunohistochemical staining of human and murine glioblastomas for $\beta 2$ microglobulin, a marker of MHC class I protein expression. To the best of our knowledge, this report is the first to describe the downregulation of $\mathrm{MHC}$ class I and II antigens in migrating and invading glioma cells, in vitro and in vivo, respectively. These results suggest that the very process of tumor invasion is associated with decreased expression of MHC antigens allowing glioma cells to invade the surrounding brain in a 'stealth'-like manner.
\end{abstract}

Laboratory Investigation (2005) 85, 328-341, advance online publication, 31 January 2005; doi:10.1038/labinvest.3700233

Keywords: gene chip; gliomas; invasion; major histocompatibility complex; microarray analysis; laser capture microdissection

Human glioblastoma multiforme (GBMs) are extremely aggressive neoplasms primarily due to their invasive potential. ${ }^{1,2}$ Recurrent tumors generally occur within $2 \mathrm{~cm}$ of the original resected tumor margin. This highly invasive nature renders most therapies for human gliomas including surgery, radiotherapy, and local drug delivery ineffective, resulting in the failure of conventional therapy to control glioma growth. ${ }^{3}$ Therefore, understanding

Correspondence: Dr D Zagzag, MD, PhD, Department of Pathology, Division of Neuropathology, New York University Medical Center, 550 First Avenue, New York, NY 10016, USA.

E-mail: dz4@nyu.edu

Received 14 July 2004; revised 24 November 2004; accepted 30 November 2004; published online 31 January 2005 the mechanisms involved in invasion of glioma cells into the brain adjacent to the main tumor mass may lead to novel and more effective treatments for GBMs.

Differences in gene expression and/or gene products between invading and noninvading glioma cells may identify potential targets for new therapies. To begin to elucidate some of the genes associated with glioma invasion, we used Affymetrix microarray Genechip ${ }^{\mathbb{R}}$ technology together with our established aggregate migration assay. ${ }^{4}$ We hypothesized that glial cell invasion would show differences in gene expression profiles associated with motility and cytoskeletal proteins, signal transduction molecules, cell surface receptors, and components of the extracellular matrix required for cell migration. 
We investigated differences in the patterns of gene expression between migrating and nonmigrating glioma cells. First, using an established in vitro model system, the aggregate migration assay, ${ }^{4}$ we analyzed the gene expression profiles in migrating and nonmigrating human LN229 glioma cells on the extracellular matrix molecule fibronectin (FN). Analysis of our gene expression profiles identified up- or downregulation of many of the same genes previously reported to be linked to glioma cell migration and invasion. Surprisingly, comparative analysis of gene expression profiles revealed downregulation of several major histocompatibility complex (MHC) class I and II molecules in migrating glioma cells. This in vitro finding was validated by RT-PCR and also confirmed in vivo using primary human GBM tumor samples. Tumor cells were collected by laser capture microdissection (LCM) from the invading edge or the main tumor core of the GBM clinical specimens. Once again, the gene expression profiles of the GBMs showed downregulation of MHC expression in the invading glioma cells. To further validate the downregulation of MHC gene expression in invading glioma tumor cells, we used immunohistochemistry for MHC protein expression in both human and murine glioma tumors. Tumor sections were stained with $\beta 2$ microglobulin as an immunohistochemical marker of MHC class I protein expression. MHC expression was diminished or absent at the invasive edge of both human and murine glioma compared with the tumor core. Our results suggest that invading glioma cells defeat the host immune surveillance system by downregulating expression of MHC molecules to escape recognition by the host (ie 'stealth invasion'). Our findings may provide a rationale for development of new immunotherapies for treatment of gliomas.

\section{Materials and methods}

Analysis of the Gene Expression Profiles of Migrating and Nonmigrating Glioma Cells In Vitro: Aggregate Migration Assay, Preparation of RNA, Generation of cDNA, and Probe Labeling

The aggregate migration assay was performed as described previously. ${ }^{4}$ Briefly, human LN229 glioma cells growing as subconfluent monolayers were trypsinized, washed three times in DMEM and resuspended in serum free DMEM/ITS + medium. Aggregates were formed and plated on FN coated plates as previously described. ${ }^{4}$ Total RNA was isolated from LN229 cells at $1 \mathrm{~h}$ (nonmigrating cells) and $16 \mathrm{~h}$ (migrating cells) by lysing with Trizol (Invitrogen, Carlsbad, CA, USA). Three independent experiments were performed.

For RNA preparation, $10 \mu \mathrm{g}$ of total RNA was used for the first strand cDNA synthesis. The biotinylated cRNA probe was prepared according to the Affymetrix protocol. Briefly, double-stranded cDNA was synthesized from total RNA (Superscript II system; Invitrogen). An in vitro transcription reaction was then performed to obtain biotin-labeled cRNA from the double-stranded cDNA (Enzo Bio Array High Yield RNA Transcript Labeling kit; Enzo Diagnostics, Inc., Farmingdale, NY, USA). In all, $70 \mu \mathrm{g}$ of biotinylated cRNA was obtained from $1.5 \times 10^{6}$ cells of migrating or nonmigrating LN229 glioma cells. A total of $15 \mu \mathrm{g}$ of cRNA was fragmented before hybridization and mixed with a hybridization mixture containing BSA and herring sperm DNA according to Affymetrix protocol. We used the human Genechip HG-U133A array, which includes 33000 well-characterized genes. Following hybridization, samples were washed and stained using GeneChip Fluidics Station 400 (Affymetrix Inc., Santa Clara, CA, USA) according to the manufacturer's recommendations. Immediately after staining, chips were scanned (Hewlett Packard, GeneArray scanner G2500A) according to procedures developed by the manufacturer.

\section{Analysis of the Gene Expression Profiles of Invading and Noninvading Glioma Cells In Vivo: Laser Capture Microdissection, Preparation of RNA, Generation of cDNA, and Probe Labeling}

This study was conducted under a protocol approved by the Institutional Review Board of New York University. Laser capture microdissection (LCM) in two human GBMs was performed to compare the gene expression profiles of tumor cells from the invading tumor edge vs cells captured from the tumor core. Serial sections (6 $\mu \mathrm{m}$ thick) from formalin-fixed, paraffin-embedded tumors were cut by a dedicated microtome to avoid crosscontamination by other specimens, and a new disposable knife was used for each specimen. The sections were mounted on glass slides and air dried, heated for $15 \mathrm{~min}$ at $60^{\circ} \mathrm{C}$ to affix sections onto the slides followed by two changes of xylene for $5 \mathrm{~min}$, immersed in 100, 95 and $70 \%$ ethanol then incubated in sterile water stained with hematoxylin and eosin and quickly dehydrated in 70,90 , and $100 \%$ ethanol air dried and kept in a dessicator overnight.

Glioma cells $(n>100)$ were captured by LCM as described in Figure 3. For each human glioma, two independent samples from the tumor core and two independent samples from the invasive edge of the tumor were collected in separate tubes to assure consistency in microarray analysis for each tumor specimen. The caps were placed into RNase-free Eppendorf tubes containing Trizol at room temperature. The RNA was extracted and precipitated with sodium acetate in the presence of glycogen carrier $(10 \mu \mathrm{g} / \mu \mathrm{l})$ in isopropanol. After the recovery of the RNA pellet, a DNase step was performed for $2 \mathrm{~h}$ at $37^{\circ} \mathrm{C}$ using $10 \mathrm{U}$ of RNase-free DNase (Promega, Madison, WI, USA), in the presence of $10 \mathrm{U}$ of 
RNase inhibitor (Life Technologies, Inc. Gaithersburg, MD), followed by phenol-chloroform extraction and precipitation. The pellet was then stored at $-70^{\circ} \mathrm{C}$ for further analysis.

\section{RNA Amplification}

The RiboAmp ${ }^{\mathrm{TM}}$ RNA Amplification Kit (Arcturus, Mountain View, CA, USA) was used for obtaining larger amounts of RNA from LCM samples. This kit allows for retention of low abundance mRNA, preventing loss of important gene expression products (ie preventing nonlinear amplification of the starting RNA population). Messenger RNA was amplified twice yielding the amount of amplified RNA sufficient for labeling and GeneChip hybridization. Biotinylated cRNA probe preparation was carried out as described above.

\section{Microarray Data Analysis}

Scanned output files were visually inspected for hybridization artifacts and then analyzed with GENECHIP 3.1 software (Affymetrix). The expression analysis file created by GENECHIP 3.1 software was transferred to a Microsoft Access database or GeneSpring 4.1 (Silicon Genetics, Redwood City, CA, USA). Using this software we scaled and normalized gene expression value to actin expression. Pathway analysis was performed using the GenMAPP software version 1.0 (Gladstone Institutes, UCSF, San Francisco, CA, USA), ${ }^{5}$ downloadable from www.genmapp.org. This software uses an identifier for each probe set to display the expression level of each gene in a pathway. We used the SwissProt identifiers for each gene based on the annotation data provided by Affymetrix, as well as a table relating GenBank identifiers to SwissProt numbers obtained with the Dragon program (pevsnerlab.kennedykrieger.org/annotate.htm). When SwissProt identifiers were not available, the GenBank identifier was used and replaced in the respective gene slot in the pathway. The annotation for each probe set of the array was verified by downloading the latest annotation files from Affymetrix. In addition, we performed BLAST analysis using the probe target sequence described by Affymetrix for all the probe sets with significant levels of expression ('Present') where there were discrepancies between various probe sets corresponding to the same transcript, or where the annotation was 'Transcribed Sequences'. When genes in a pathway were not automatically found in the array with the GenMAPP software, we used NCBI BLASTN (http://www.ncbi.nlm.nih.gov/ BLAST/) and BLAT alignments to the UCSC genome browser (http://genome.ucsc.edu) ${ }^{6}$ to identify sequences homologous to the probes in the array. Using these strategies, we assigned a specific gene (with the corresponding HUGO Gene Nomenclature approved gene symbol) to 7250 Rae230 probe sets corresponding to 5664 different genes, as compared to the original 5193 probe sets corresponding to 4662 different genes from the Affymetrix annotation files. All the pathways in the GenMAPP database were analyzed to determine if a significant number of genes were affected. ${ }^{7}$ To be selected, genes had to show $\geq 2$-fold changes in gene expression. ${ }^{8}$ The $z$-score was derived by dividing the difference between the observed number of genes meeting the criterion in a specific group or pathway and the expected number of genes based on the total number of genes in the array meeting the criterion and standardizing by dividing by the standard deviation of the observed number of genes under the hypergeometric distribution. A positive $z$-score indicates that more genes than expected fulfill the criterion in a certain group or pathway.

The equation used was:

$$
z=\frac{\left(r-n \frac{R}{N}\right)}{\sqrt{n\left(\frac{R}{N}\right)\left(1-\frac{R}{N}\right)\left(1-\frac{n-1}{N-1}\right)}}
$$

where $N$ is the total number of genes measured in the array, $R$ is the total number of genes meeting the criterion, $n$ is the total number of genes in a specific group or pathway and $r$ is the number of genes meeting the criterion in a specific group or pathway.

\section{RNA Purification and Reverse Transcription-PCR (RT-PCR) Analysis}

LN229 glioma cell culture and the aggregate migration assay were performed as described above. Total RNA was isolated from migrating and nonmigrating LN229 glioma cells using Trizol (Invitrogen, Carlsbad, CA, USA), according to manufacturer instructions. RNA was precipitated from the Trizol reagent with isopropanol and resuspended in DEPC- $\mathrm{H}_{2} \mathrm{O}$. For reverse transcription, $1 \mu \mathrm{g}$ of total RNA was reverse-transcribed using Super Script II RNase H reverse transcriptase (Invitrogen, Carlsbad, CA, USA) and random hexamer primers (Invitrogen, Carlsbad, CA, USA) at $25^{\circ} \mathrm{C}$ for $10 \mathrm{~min}$ and $42^{\circ} \mathrm{C}$ for $1 \mathrm{~h}$ for cDNA synthesis. The reverse transcription product $(1.5 \mu \mathrm{l})$ was used as a template for PCR amplification. PCR was performed under standard conditions in a $50 \mu \mathrm{l}$ reaction mix containing $1 \times$ PCR buffer, $1 \mathrm{U}$ of Platinum Taq polymerase (Invitrogen, Carlsbad, CA, USA), $200 \mu \mathrm{M}$ dNTP mix, $1.5 \mathrm{mM} \mathrm{MgCl}$. Primers used are listed in Table 1 and were designed using MIT Primer3 software as previously described. ${ }^{9}$ The PCR reactions were comprised of $3 \mathrm{~min}$ of an initial denaturation step $\left(95^{\circ} \mathrm{C}\right)$ followed by 23 cycles of denaturation $\left(95^{\circ} \mathrm{C}\right.$, $30 \mathrm{~s})$, annealing $\left(55^{\circ} \mathrm{C}, 30 \mathrm{~s}\right)$, and extension $\left(72^{\circ} \mathrm{C}\right.$, $50 \mathrm{~s}$ ) followed by a final elongation step of $5 \mathrm{~min}$ at $72^{\circ} \mathrm{C}$. In all, $15 \mu \mathrm{l}$ of PCR products were analyzed on $3 \%$ agarose gels stained with ethidium bromide 
Table 1 PCR Primers used for RT-PCR

\begin{tabular}{|c|c|c|}
\hline Gene & Sequence & $\begin{array}{l}\text { Product } \\
\text { (bp) }\end{array}$ \\
\hline MHC class I & $\begin{array}{l}\text { CCTCTGGCATCTCTTTCTGC (s) } \\
\text { CCACCTCTCTGGAACAGGAA (as) }\end{array}$ & 163 \\
\hline MHC class II & $\begin{array}{l}\text { CCCAACGTCCTCATCTGTTT (s) } \\
\text { AGCATCAAACTCCCAGTGCT (as) }\end{array}$ & 243 \\
\hline TIMP3 & $\begin{array}{l}\text { CCTGCTACTACCTGCCTTGC (s) } \\
\text { TGTGGCATTGATGATGCTTT (as) }\end{array}$ & 182 \\
\hline $\mathrm{tPA}$ & $\begin{array}{l}\text { CAAGTCTCCTTCCCCTTTCC (s) } \\
\text { GGGTTGTGGCAACAGAAAGT (as) }\end{array}$ & 190 \\
\hline$\beta$-actin & $\begin{array}{l}\text { GTACCACTGGCATCGTGATGGACT (s) } \\
\text { ATCCACACGGAGTACTTGCGCTCA (as) }\end{array}$ & 600 \\
\hline
\end{tabular}

(EtBr). Two independent experiments were performed.

\section{Experimental Murine GL261 Glioma}

We have successfully developed an in vivo animal model using green fluorescence protein (GFP)tagged GL261 glioma cells implanted in the brain of syngeneic C57BL/6 mice. ${ }^{10}$ This experimental system allows us to identify invading glioma cells and study the process by which they migrate into surrounding brain tissue. GL261 murine glioma cells were obtained from the NCI-Frederick Cancer Research Tumor Repository (Frederick, MD, USA) and were transfected with a plasmid encoding the gene for GFP, as described. ${ }^{10}$ GL261 glioma cells were implanted in the brains of C57BL/6 mice as described. ${ }^{10}$ The GFP-tagged GL261 tumors showed areas of necrosis, vascularity, nuclear pleomorphism, mitotic figures, and pseudopalisading cells around areas of necrosis, all histopathological features indistinguishable from the histopathology associated with GBMs. ${ }^{10}$

\section{Immunohistochemistry}

Single and double label immunohistochemistry was performed using the NexES automated immunostainer and detection systems (Ventana Medical Systems, Tucson, AZ, USA). Formalin-fixed, paraffinembedded, $6 \mu \mathrm{m}$ sections were deparaffinized in xylene (three changes), rehydrated through graded alcohols (three changes $100 \%$ ethanol, three changes $95 \%$ ethanol) and rinsed in distilled water. All incubations were carried out at $37^{\circ} \mathrm{C}$ unless otherwise noted.

To visualize human tumor cells invading the brain adjacent to tumor (BAT), we immunostained tissue sections of 21 p53-positive GBMs with mouse antihuman p53 (clone DO7; Novacastra Laboratories, Newcastle upon Tyne, UK). Included among these were the two cases used for LCM. Heat-induced epitope retrieval was performed by microwaving tissue sections in $0.01 \mathrm{M}, \mathrm{pH} 6.0$ citrate buffer for $20 \mathrm{~min}$ in a $1200 \mathrm{~W}$ microwave oven. Slides were allowed to cool to room temperature then washed in $0.05 \mathrm{M}$ Tris-HCl, pH 7.6 containing $0.3 \mathrm{M} \mathrm{NaCl}$. Endogenous peroxidase was blocked by application of hydrogen peroxide for $4 \mathrm{~min}$ at $37^{\circ} \mathrm{C}$. Anti-p53 antibody was diluted 1:50 and applied for $32 \mathrm{~min}$. Primary antibody was detected by application of a secondary biotinylated goat anti-mouse (Ventana Medical Systems) for $8 \mathrm{~min}$, followed by the application of streptavidin-horseradish peroxidase for $8 \mathrm{~min}$. The chromogen, 3,3'-diaminobenzidine/hydrogen peroxide mix was applied for $8 \mathrm{~min}$ and then enhanced with copper sulfate for 4 min. Slides were then counterstained with hematoxylin, dehydrated and mounted with Permount ${ }^{\mathbb{R}}$. To detect MHC class I expressing cells in human tissue, sections were immunostained with rabbit anti-human/mouse $\beta 2$ microglobulin antibody (Novocastra). This antibody reacts with the light chain component of MHC class I molecules. ${ }^{11}$ Antigen retrieval was performed by proteolytic enzyme digestion (alkaline endopeptidase $0.5 \mathrm{U} / \mathrm{ml}$ Ventana Medical Systems, Tucson, AZ, USA) for $4 \mathrm{~min}$. Endogenous peroxidase was blocked by application of hydrogen peroxide for 4 min. Anti- $\beta 2$ microglobulin was diluted 1:300 and applied for $32 \mathrm{~min}$. Primary antibody was detected as described above.

To detect MHC class I expressing cells in mouse tissue, sections were immunostained as described above except with anti- $\beta 2$ microglobulin diluted 1:1000. To detect murine GL261 tumor cells invading the BAT, we immunostained tissue sections with mouse anti-GFP (clone GFP01; Neomarkers Fremont, CA, USA) as described previously. ${ }^{10} \mathrm{We}$ studied four tumors, each at stage 5 of tumor progression, where the tumor core and the invading edge of the tumor into the BAT were clearly identified..$^{10,12}$ For double label immunohistochemistry, tumor sections were stained first with $\beta 2$ microglobulin. Heat-induced antigen retrieval was performed as described above. Next, the slides were incubated with anti-GFP antibody at 1:300 and incubated overnight at room temperature. GFP antibody was detected as described above using alkaline phosphatase fast red as chromogen.

\section{Results}

\section{Downregulation of MHC Gene Expression in Migrating} Human LN229 Glioma Cells In Vitro

To investigate genes that are differentially expressed in migrating glioma cells in vitro, we used the aggregate migration assay with human LN229 glioma cells plated on the extracellular matrix protein FN (Figure 1) as previously described. ${ }^{4}$ We compared the gene expression profiles associated with migrating vs nonmigrating LN229 glioma cells. At $1 \mathrm{~h}$ after plating, LN229 cells had not migrated from the aggregates (Figure 1a), compared with $16 \mathrm{~h}$ 

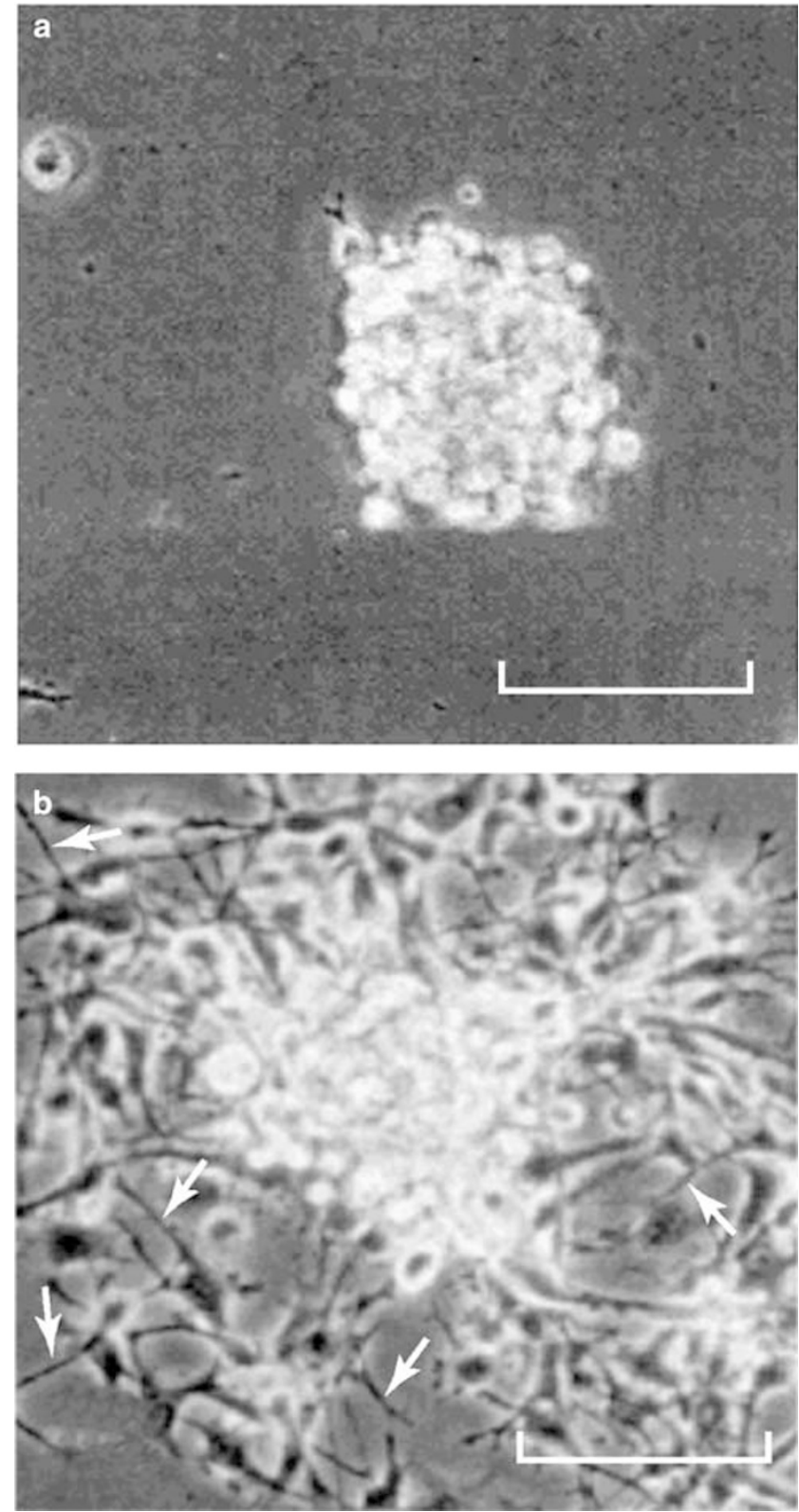

Figure 1 Migration of LN229 glioma cells in vitro. Aggregates were prepared overnight and plated on FN $(100 \mu \mathrm{g} / \mathrm{ml})$ as described in Materials and methods. Migration was monitored by obtaining micrographs at $1 \mathrm{~h}$ and $16 \mathrm{~h}$. (a) At $1 \mathrm{~h}$, there was no cellular migration from the aggregates. (b) In contrast, at $16 \mathrm{~h}$ the glioma cells had migrated extensively. The cells exhibit spreading and show long processes (arrows). Note the morphology adopted by the glioma cells seeded on FN and the tendency to exhibit ellipsoidal shape on this substrate. Scale bar corresponds to $100 \mu \mathrm{m}$.

where extensive migration had taken place (Figure 1b). RNA collected from LN229 cells $1 \mathrm{~h}$ or $16 \mathrm{~h}$ after plating aggregates on FN was hybridized to the Affymetrix chip.

We observed 263 genes that showed $\geq 2$-fold changes in gene expression. Table 2 shows genes that were selected based on the following criteria: (i) they were up- or downregulated beyond our cutoff threshold of $\geq 2$-fold; (ii) they were previously associated with glioma cell migration or invasion and identified by Affymetrix microarray analysis; or (iii) they were linked to glioma cell migration or invasion by studies of gene or protein expression. Many of the upregulated genes were previously associated with glioma cell migration including: tropomyosin $1 \alpha, \alpha 2$ macroglobulin, tissue plasminogen activator (tPA), and tumor necrosis factor receptor (member 1a). ${ }^{13-16}$ Genes that were downregulated fulfilling our criteria included tissue inhibitor of metalloproteinase 3 (TIMP3), GTPase regulator, and transgelin 2. ${ }^{17-19}$ GTPase regulator is linked to focal adhesion kinase (FAK). FAK has been implicated in glioma cell migration in vitro and glioma cell invasion in vivo. ${ }^{4,20}$ Surprisingly, eight different MHC class I and class II genes were downregulated. As a result of this unexpected finding, we next confirmed decreased MHC gene expression using RT-PCR (Figure 2). Total RNA was extracted from migrating $(16 \mathrm{~h})$ and nonmigrating (1 h) LN229 glioma cells. We found that MHC class I and MHC class II expression was downregulated in migrating vs nonmigrating cells. We also investigated the gene expression of two other genes identified in Table 2 that are critically associated with glioma cell migration, that is, tPA and TIMP3. Consistent with their role in glioma cell migration tPA was upregulated, while TIMP3 was downregulated.

\section{Downregulation of MHC Gene Expression in LCM-Captured Invading Glioma Cells in Primary Human GBMs In Vivo}

To validate the in vitro data obtained in migrating human LN229 glioma cells, we performed LCM in two human GBM specimens to obtain gene expression profiles in invading vs noninvading glioma cells. For each human GBM specimen, two independent samples from the tumor core and two independent samples from the invasive edge of the tumor were collected in separate tubes to assure reproducibility and consistency in microarray analysis (Figure 3).

We observed 187 genes that showed $\geq 2$-fold changes in gene expression. Table 3 shows genes that were selected based on our established criteria. Many of the upregulated genes have been previously associated with glioma cell migration, including vinculin, insulin-like growth factor binding protein, hepatocyte growth factor, tumor necrosis factor (ligand) superfamily (member 9), astrotactin, mitogen-activated protein kinase 3 , vitronectin, laminin, serine protease 11 (PRSS11), ionotropic glutamate receptor, and catenin. ${ }^{21-30}$ Importantly, similar to migrating LN229 glioma cells in vitro, MHC genes were downregulated in vivo in the tumor cells located at the invasive edge of the clinical GBM samples (Table 3). 
Table 2 Selected gene changes in migrating human LN229 glioma cells in vitro ${ }^{\mathrm{a}}$

\begin{tabular}{|c|c|c|c|c|}
\hline GeneBank \# & Affymetrix ID & Fold & Gene description & Function $^{\mathrm{b}}$ \\
\hline \multicolumn{5}{|c|}{ Genes upregulated } \\
\hline NM_00036.1 & 206117_at & 3.89 & Tropomyosin $1 \alpha$ & $\begin{array}{l}\text { Associated with the actin filaments of myofibrils } \\
\text { and stress fibers }\end{array}$ \\
\hline NM_000014.3 & 201383_s_at & 3.25 & $\alpha 2$-macroglobulin & $\begin{array}{l}\text { A cytokine transporter and protease inhibitor of } \\
\text { trypsin, thrombin and collagenase }\end{array}$ \\
\hline NM_000930 & 201860_s_at & 2.71 & $\begin{array}{l}\text { Tissue plasminogen } \\
\text { activator }\end{array}$ & $\begin{array}{l}\text { Serine protease which converts the proenzyme } \\
\text { plasminogen to plasmin. Plays a role in cell } \\
\text { migration and tissue remodeling }\end{array}$ \\
\hline NM_001065.1 & 207643_s_at & 2.25 & TNF receptor, member $1 \mathrm{a}$ & $\begin{array}{l}\text { Can activate NF-kappaB, and enhances glioma } \\
\text { cell motility and invasiveness }\end{array}$ \\
\hline \multicolumn{5}{|c|}{ Genes downregulated } \\
\hline M60334.1 & 208894_at & 9.25 & $\begin{array}{l}\text { MHC class II surface } \\
\text { glycoprotein/HLA-DRA }\end{array}$ & Presentation of antigenic peptides to CD4+ T cells \\
\hline D83043.1 & 208429_x_at & 9.13 & MHC class I, B/HLA-B & Presentation of antigenic peptides to CD8+ T cells \\
\hline NM_00024.1 & 205905_s_at & 9.02 & $\begin{array}{l}\text { MHC class I chain-related } \\
\text { gene A protein }\end{array}$ & $\begin{array}{l}\text { Stress-induced ligand for } \gamma \delta \text {-T cells and NK-T } \\
\text { cells }\end{array}$ \\
\hline U67195.1 & 201149_s_at & 5.88 & TIMP3 & $\begin{array}{l}\text { Natural inhibitor of the metalloproteinases. } \\
\text { Metalloproteinases' action facilitates glioma } \\
\text { invasion and metastasis }\end{array}$ \\
\hline L42024.1 & 209140_x_at & 5.32 & MHC class I, B/HLA-B39 & Presentation of antigenic peptides to CD8+ T cells \\
\hline AJ297586.1 & 215193_x_at & 4.53 & $\begin{array}{l}\text { MHC class II antigen/ } \\
\text { HLA-DRB1 }\end{array}$ & Presentation of antigenic peptides to CD4+ T cells \\
\hline U65585.1 & 209312_x_at & 4.00 & $\begin{array}{l}\text { MHC class II antigen/ } \\
\text { HLA-DRB1 }\end{array}$ & Presentation of antigenic peptides to CD4+ T cells \\
\hline NM_00212.1 & 204670_x_at & 3.85 & $\begin{array}{l}\text { MHC class II, DR beta } \\
\text { 5/HLA-DRB5 }\end{array}$ & Presentation of antigenic peptides to CD4+ T cells \\
\hline BE671084 & 205068_s_at & 3.70 & $\begin{array}{l}\text { GTPase regulator linked } \\
\text { to FAK pp125 }\end{array}$ & $\begin{array}{l}\text { Negative regulator of RhoA. RhoA promotes } \\
\text { migration and invasion by endothelial cells }\end{array}$ \\
\hline NM_002198.2 & 208306_x_at & 3.65 & $\begin{array}{l}\text { MHC class II DR beta } \\
\text { 4/HLA-DRB4 }\end{array}$ & Presentation of antigenic peptides to CD4+ T cells \\
\hline BC002616.1 & 210978_s_at & 3.22 & Transgelin 2 & $\begin{array}{l}\text { A transformation and shape-change sensitive } \\
\text { actin crosslinking/gelling protein. Expression is } \\
\text { downregulated in a variety of human breast, } \\
\text { colon, and fibrosarcoma tumor cell lines }\end{array}$ \\
\hline
\end{tabular}

${ }^{\mathrm{a}}$ Genes were selected based on the following criteria: (i) they were up- or downregulated beyond our cutoff threshold of $\geq 2$-fold. The fold changes are shown and were calculated as in 'Materials and methods'; (ii) they were previously associated with glioma cell migration or invasion and identified by Affymetrix microarray analysis; or (iii) they were linked to glioma cell migration or invasion by studies of gene or protein expression.

${ }^{b}$ Information on genes listed in this table is taken from Entrez Gene.

\section{MHC Class I Protein Expression in Invading Glioma Cells In Vivo: Validation Study in Human GBMs by Immunohistochemistry}

To determine whether the downregulation of mRNA for MHC genes observed in the microarray experiments correlated with a decrease of MHC class I protein expression in vivo, an immunohistochemical approach was used. $\beta 2$ microglobulin, the light chain subunit of MHC class I molecules, was used as an immunohistochemical marker for MHC class I expression. Serial tumor sections from 21 clinical paraffin-embedded GBM specimens were immunostained either with an antibody specific for $\beta 2$ microglobulin or an antibody for p53 protein that we used as a marker to detect invading glioma cells in p53-positive specimens. We compared the levels of protein expression as well as the distribution of $\beta 2$ microglobulin-positive tumor cells in relation to p53-positive tumor cells in all the tumors. Repre- sentative sections of one human GBM are shown in Figure 4. The immunohistochemical findings shown were consistent for all the GBMs analyzed. A notable feature of sections stained with $\beta 2$ microglobulin was the intense immunoreactivity of vascular channels both within the tumor core and at the invading edge of the tumors as previously described. ${ }^{31}$ We observed a differential expression of $\beta 2$ microglobulin at the invasive edge of the tumor as compared to the tumor core. $\beta 2$ microglobulin was highly expressed in tumor cells within the tumor core. However, its expression decreased from strong to weak immunoreactivity moving from tumor core to the invading edge of the tumor, respectively. Glioma cells invading the BAT, easily detected by p53 immunostaining (Figure 4a-c), either were negative or were markedly decreased for $\beta 2$ microglobulin expression (Figure $4 \mathrm{~d}-\mathrm{f}$ ). Thus, at the tumor core, tumor cells were double positive for p53 and $\beta 2$ microglobulin immmunoreactivity, 


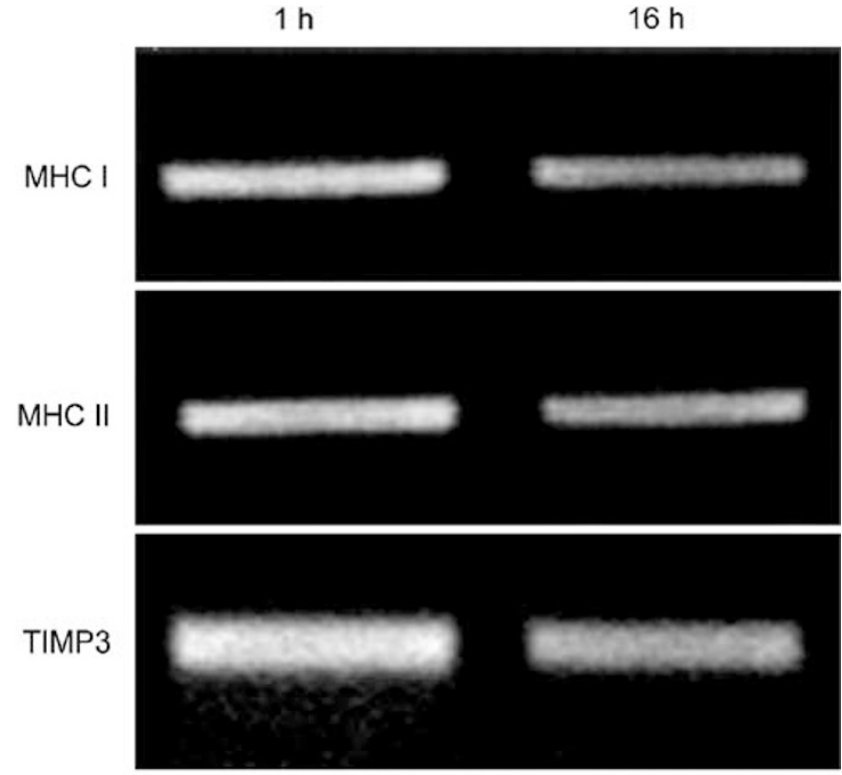

PA

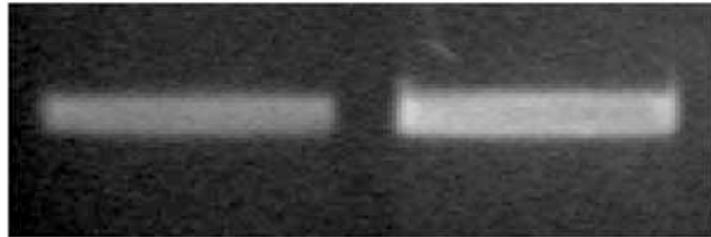

$\beta$-actin

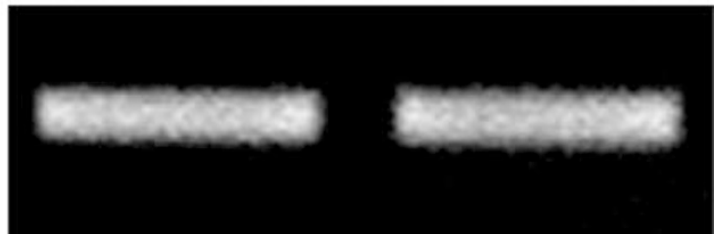

Figure 2 RT-PCR analysis of gene expression in migrating and nonmigrating LN229 glioma cells in vitro. Total RNA was isolated and reverse-transcribed from migrating $(16 \mathrm{~h})$ and nonmigrating (1 h) LN229 glioma cells. Results are shown for MHC class I, MHC class II, TIMP3, and tPA genes. $\beta$-actin expression was included as an internal control. The data are representative of one of two independent experiments with similar results. PCR products were resolved on a 3\% agarose gel and visualized by EtBr staining.

while p53 positive invading glioma cells showed decreased expression for $\beta 2$ microglobulin immunoreactivity.

\section{MHC Class I Protein Expression in Invading Glioma Cells In Vivo: Validation Study in Murine GL261 Gliomas by Double Immunohistochemistry}

To further confirm the downregulation of MHC gene expression in invading glioma cells, we used our murine GL261 glioma model. ${ }^{10}$ This animal model closely mimics the invasive growth pattern associated with human GBMs. ${ }^{10}$ We showed that GFPtagged GL261 tumor cells, including those at the invasive edge of murine gliomas, are readily identified by anti-GFP immunostaining. ${ }^{10}$ Representative sections of one GL261 brain tumor are shown in Figure 5. Invasion of the BAT by GFP-tagged GL261 glioma cells occurred as isolated single cells (Figure 5a) and as groups of cells around vascular channels as previously described. ${ }^{10}$ For these studies, we used a double immunostaining approach to investigate the expression of $\beta 2$ microglobulin and GFP expression in a single tumor cell. We compared the levels of expression as well as the distribution of $\beta 2$ microglobulin in relation to GFP-positive GL261 glioma cells in the tumors. The findings shown were consistent for all four GL261 tumors examined. Invading GL261 tumor cells identified by positive GFP staining in the BAT lacked immunoreactivity for $\beta 2$ microglobulin (Figure $5 \mathrm{~b}$ ), while noninvading cells within the tumor core were positive for $\beta 2$ microglobulin and GFP expression (Figure 5c). Thus, as in human GBMs, MHC class I expression in invading murine GL261 glioma cells was absent or markedly decreased.

\section{Discussion}

Despite multimodality therapy, patients with GBMs, the most malignant astrocytomas, rarely survive 612 months after diagnosis. ${ }^{3}$ Current therapies such as surgical excision, radiation, and chemotherapy have done little to improve the clinical course of these patients. ${ }^{3}$ One reason for this therapeutic failure is the marked invasive nature of gliomas. ${ }^{3}$ Gene expression profiling demonstrated that many genes previously associated with migration and invasion of human glioma cells showed altered levels of expression. ${ }^{13-30}$ Surprisingly, however, our analysis also revealed downregulation of several MHC class I and II genes in migrating LN229 glioma cells in vitro that was confirmed by RT-PCR analysis. In addition, consistent with these findings, immunohistochemistry of invading GBM tumor cells in vivo demonstrated decreased MHC class I protein expression, in invading glioma cells compared to the high levels of expression observed within the tumor core in both human and murine gliomas. Downregulation of MHC expression in GBMs may defeat the host immune surveillance system by preventing their recognition by immunocompetent cells (ie 'stealth invasion').

Invasion of glioma cells into surrounding brain tissue may be associated with at least two processes, both of which defeat the immune surveillance mechanisms of the host: (i) production of gliomaderived immunosuppressive factors; and (ii) downregulation of $\mathrm{MHC}$ antigens in migrating and invading glioma cells. Glioma-mediated immunosuppression and downregulation of the host immune response has been associated with the release of immunosuppressive factors by glioma cells, for example, transforming growth factor (TGF)- $\beta 1, \beta 2$, and $\beta 3 .^{32-38}$ In addition to TGF- $\beta$, other factors capable of inhibiting immune function ${ }^{37}$ include the cytokines interleukin (IL)-6 and IL- $10,{ }^{39-45}$ prostaglandin $\mathrm{E}^{46-50}$ and gangliosides. ${ }^{51}$ TGF- $\beta 1$ 

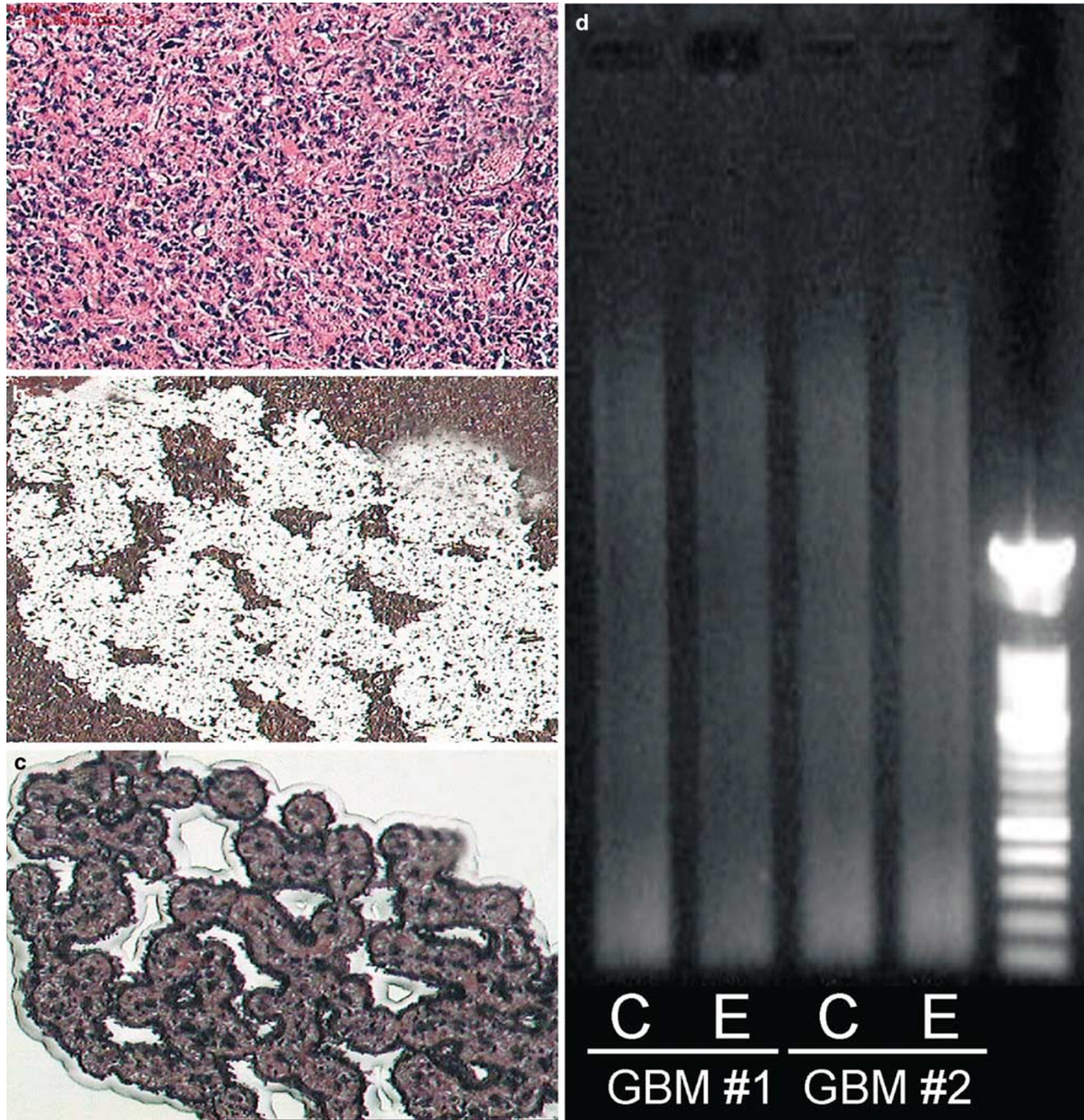

Figure 3 LCM of human GBMs and preparation of cRNAs. Tumor cells from a formalin-fixed, paraffin-embedded GBM sample were harvested using LCM from the core or from the invading edge of the tumor. LCM was performed with a Pixcell laser microdissector (Arcturus Engineering, Mountain View, CA, USA) as described in Materials and methods. Digital images of the tissue section were captured before and after each LCM cell harvest. (a) H\&E-stained section of the tumor core prior to LCM procedure, (original magnification $\times 200$ ). (b) The same tissue section after LCM showing microdissection of the tumor cells. (c) Specific cluster of cells from the tissue section after LCM used for RNA isolation (adherent to membranes corresponding to the gap in b). (d) cRNAs obtained from microdissected GBMs. RNA was obtained from > 100 cells in LCM samples from each of two GBMs (GBM \#1 and \#2) as described in Materials and Methods. To check the quality of the amplified cRNAs, $3 \mu \mathrm{l}$ out of $25 \mu \mathrm{l}$ of the total cRNA sample were loaded per lane onto an agarose gel. Representative samples from the invasive edge (E) and the viable tumor core (C) demonstrate consistent high-quality cRNAs. Molecular weight marker XIV was used for molecular weight verification. Following gel analysis, the remainder of the cRNA sample was used for hybridization to the Affymetrix human gene chip. Duplicate samples obtained from each GBM were hybridized to different gene chips (total of four chips/GBM).

and IL-10 act by suppressing $\mathrm{T}$ cell function. ${ }^{42,52}$ Increased levels of the cytokines IL-6 and IL-10 can shift the immune response from $\mathrm{T}$ helper 1 (cell-mediated) immune response to a $\mathrm{T}$ helper 2 (humoral) immune response, the latter is less effective in eradicating tumors. ${ }^{53,54}$ 
Table 3 Selected genes changes in invading glioblastoma cells in vivo

\begin{tabular}{|c|c|c|c|c|}
\hline GeneBank \# & Affymetrix ID & Fold & Gene description & Function $^{\mathrm{b}}$ \\
\hline \multicolumn{5}{|c|}{ Genes upregulated } \\
\hline NM_014000 & 200931_s_at & 50.48 & Vinculin & $\begin{array}{l}\text { Cytoskeletal protein associated with cell-cell } \\
\text { and cell-matrix junctions, involved in anchoring } \\
\text { F-actin to the membrane }\end{array}$ \\
\hline NM_000599 & 203425_s_at & 13.54 & $\begin{array}{l}\text { Insulin-like growth factor } \\
\text { binding protein } 5\end{array}$ & $\begin{array}{l}\text { A growth inhibitor and proapoptotic agent } \\
\text { involved in } \mathrm{G} 2 / \mathrm{M} \text { cell cycle arrest. Enhances } \\
\text { glioblastoma invasion by activating invasion } \\
\text { enhancing genes }\end{array}$ \\
\hline NM_006384 & 201953_at & 12.23 & $\begin{array}{l}\text { Calcium and integrin } \\
\text { binding-protein }\end{array}$ & $\begin{array}{l}\text { May be a regulatory molecule for integrin } \\
\text { alpha(IIb)beta(3) }\end{array}$ \\
\hline U46010 & 210755_at & 11.57 & Hepatocyte growth factor & $\begin{array}{l}\text { Induces proliferation, survival, dissociation, } \\
\text { motility, and invasiveness of glioma cells }\end{array}$ \\
\hline NM_007038 & 219935_at & 11.47 & $\begin{array}{l}\text { A disintegrin-like and } \\
\text { metalloprotease }\end{array}$ & $\begin{array}{l}\text { Cleaves aggrecan, a major proteoglycan of } \\
\text { cartilage }\end{array}$ \\
\hline NM_003811 & 206907_at & 11.08 & $\begin{array}{l}\text { TNF superfamily, } \\
\text { member } 9\end{array}$ & $\begin{array}{l}\text { This cytokine and its receptor are involved in the } \\
\text { antigen presentation process, and in the } \\
\text { generation of cytotoxic T cells. This cytokine is } \\
\text { also shown to be required for the optimal CD8 } \\
\text { responses in CD8+ T cells }\end{array}$ \\
\hline AL031290 & 213332_at & 10.31 & Astrotactin & $\begin{array}{l}\text { Required for young neurons to migrate along glial } \\
\text { fibers to find their correct positions in the } \\
\text { growing brain }\end{array}$ \\
\hline NM_001464 & 207664_at & 8.96 & $\begin{array}{l}\text { A disintegrin-like and } \\
\text { metalloprotease }\end{array}$ & $\begin{array}{l}\text { Implicated in a variety of processes involving } \\
\text { cell-cell and cell-matrix interactions including } \\
\text { fertilization, muscle development, and } \\
\text { neurogenesis }\end{array}$ \\
\hline X61088 & 212046_x_at & 8.55 & $\begin{array}{l}\text { Mitogen-activated protein } \\
\text { kinase } 3\end{array}$ & $\begin{array}{l}\text { A signal transduction molecule involved in cell } \\
\text { cycle regulation }\end{array}$ \\
\hline NM_000638 & 204534_at & 5.83 & Vitronectin & $\begin{array}{l}\text { Promotes cell adhesion and spreading, inhibits } \\
\text { the membrane-damaging effects of the terminal } \\
\text { cytolytic compliment pathway, and binds to } \\
\text { several serpin serine protease inhibitors }\end{array}$ \\
\hline BC003355 & 210150_s_at & 5.24 & Laminin $\alpha 5$ & $\begin{array}{l}\text { Mediates the attachment, migration, and } \\
\text { organization of cells into tissues during } \\
\text { embryonic development by interaction with } \\
\text { other extracellular matrix components }\end{array}$ \\
\hline AB002364 & 214913_at & 4.26 & $\begin{array}{l}\text { A disintegrin-like and } \\
\text { metalloprotease }\end{array}$ & Procollagen II N-propeptidase \\
\hline NM_002775 & 201185_at & 3.92 & Serine protease 11 & $\begin{array}{l}\text { Regulates the availability of insulin-like growth } \\
\text { factors; also a regulator of cell growth }\end{array}$ \\
\hline NM_000426 & 205116_at & 3.57 & Laminin $\alpha 2$ (Merosin) & $\begin{array}{l}\text { Mediates the attachment, migration, and } \\
\text { organization of cells into tissues during } \\
\text { embryonic development by interaction with } \\
\text { other extracellular matrix components }\end{array}$ \\
\hline NM_000826 & 205358_at & 2.58 & $\begin{array}{l}\text { Ionotropic glutamate } \\
\text { receptor }\end{array}$ & $\begin{array}{l}\text { Overexpression of this predominant excitatory } \\
\text { neurotransmitter receptor in the mammalian } \\
\text { brain facilitates migration and proliferation of } \\
\text { glioblastoma cells }\end{array}$ \\
\hline AF035302 & 209617_s_at & 2.23 & $\begin{array}{l}\text { Catenin (cadherin- } \\
\text { associated protein) } \delta 2\end{array}$ & $\begin{array}{l}\text { Links cytoplasmic regions of cadherins to the } \\
\text { actin cytoskeleton }\end{array}$ \\
\hline \multicolumn{5}{|c|}{ Genes downregulated } \\
\hline AK024836 & 216526_x_at & 14.28 & MHC class I, HLA-C & Presentation of antigenic peptides to CD8+ T cells \\
\hline NM_000247 & 205904_at & 6.66 & $\begin{array}{l}\text { MHC class I polypeptide- } \\
\text { related sequence }\end{array}$ & $\begin{array}{l}\text { Stress-induced ligand for } \gamma \delta \text {-T cells and NK-T } \\
\text { cells }\end{array}$ \\
\hline NM_004048 & 201891_s_at & 6.61 & $\beta$-2-microglobulin & Subunit of MHC class I antigens \\
\hline
\end{tabular}

${ }^{\mathrm{a}}$ Genes were selected based on the following criteria: (i) they were up- or downregulated beyond our cutoff threshold of $\geq 2$-fold. The fold changes are shown and were calculated as in 'Materials and methods'; (ii) they were previously associated with glioma cell migration or invasion and identified by Affymetrix microarray analysis; or (iii) they were linked to glioma cell migration or invasion by studies of gene or protein expression.

${ }^{\mathrm{b}}$ Information on genes listed in this table is taken from Entrez Gene.

The mechanism of escape from immune surveillance by downregulation of MHC is different from glioma-mediated immunosuppression. The idea that decreased MHC expression protects tumor cells from immune surveillance is not new. ${ }^{31,55-58}$ In order to be recognized by cytotoxic T cells, tumor antigens 

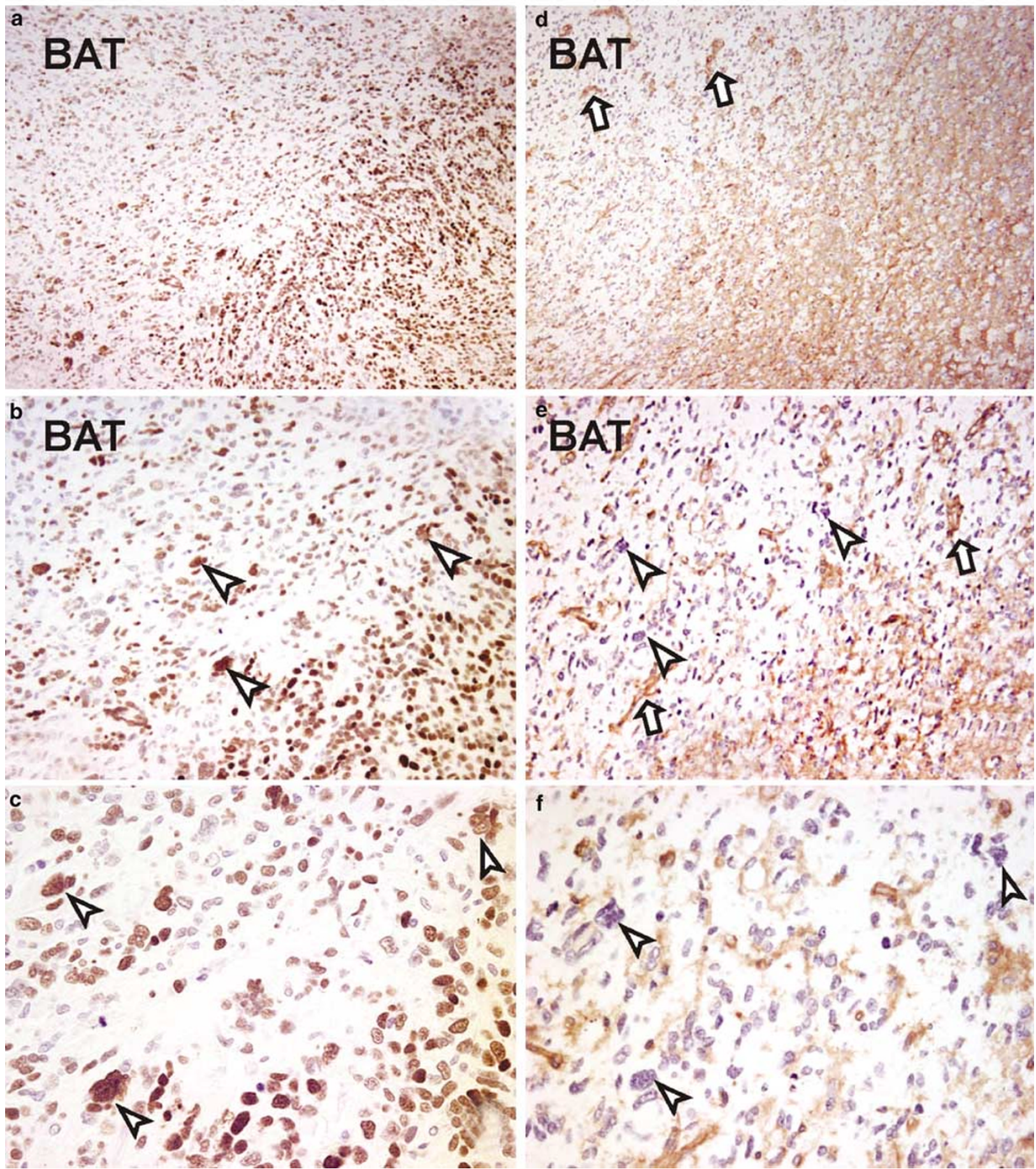

Figure 4 Downregulation of MHC class I expression at the invasive edge of GBM. A representative section of a GBM invading the BAT immunostained for p53 (a-c) or $\beta 2$ microglobulin $(\mathbf{d}-\mathbf{f})$. (a) Glioma cells within the tumor core and invading the BAT are easily detected by their p53 immunoreactivity. p53-positive glioma cells are more numerous in the tumor as compared to those seen invading the BAT; (b) A mid power view highlights the border between the tumor against the surrounding BAT. Three p53-positive glioma cells are indicated by arrowheads; (c) A high-power view shows several p53-positive glioma cells invading the BAT (arrowheads); (d) $\beta 2$ microglobulin immunoreactivity in the tumor core and the BAT. In the tumor core the immunoreactivity is diffuse and consistent with a membranous pattern of staining. There is decreased expression from strong to weak moving from tumor core to the advancing edge of the tumor, respectively. Note the strong vascular staining (arrows); (e) $\beta 2$ microglobulin is highly expressed in tumor cells within the tumor core. Invading glioma cells in the BAT are devoid of $\beta 2$ microglobulin immunoreactivity. Immunoreactive vascular channels are highlighted by arrows; (f) A higher power view shows the same p53 immunoreactive invading glioma cells in c lack $\beta 2$ microglobulin immunoreactivity (arrowheads). (a-f are serial sections; a\&d, original magnification $\times 100$, b\&e, original magnification $\times 200$; $\mathbf{c} \& \mathbf{f}$, original magnification $\times 400$ ). 

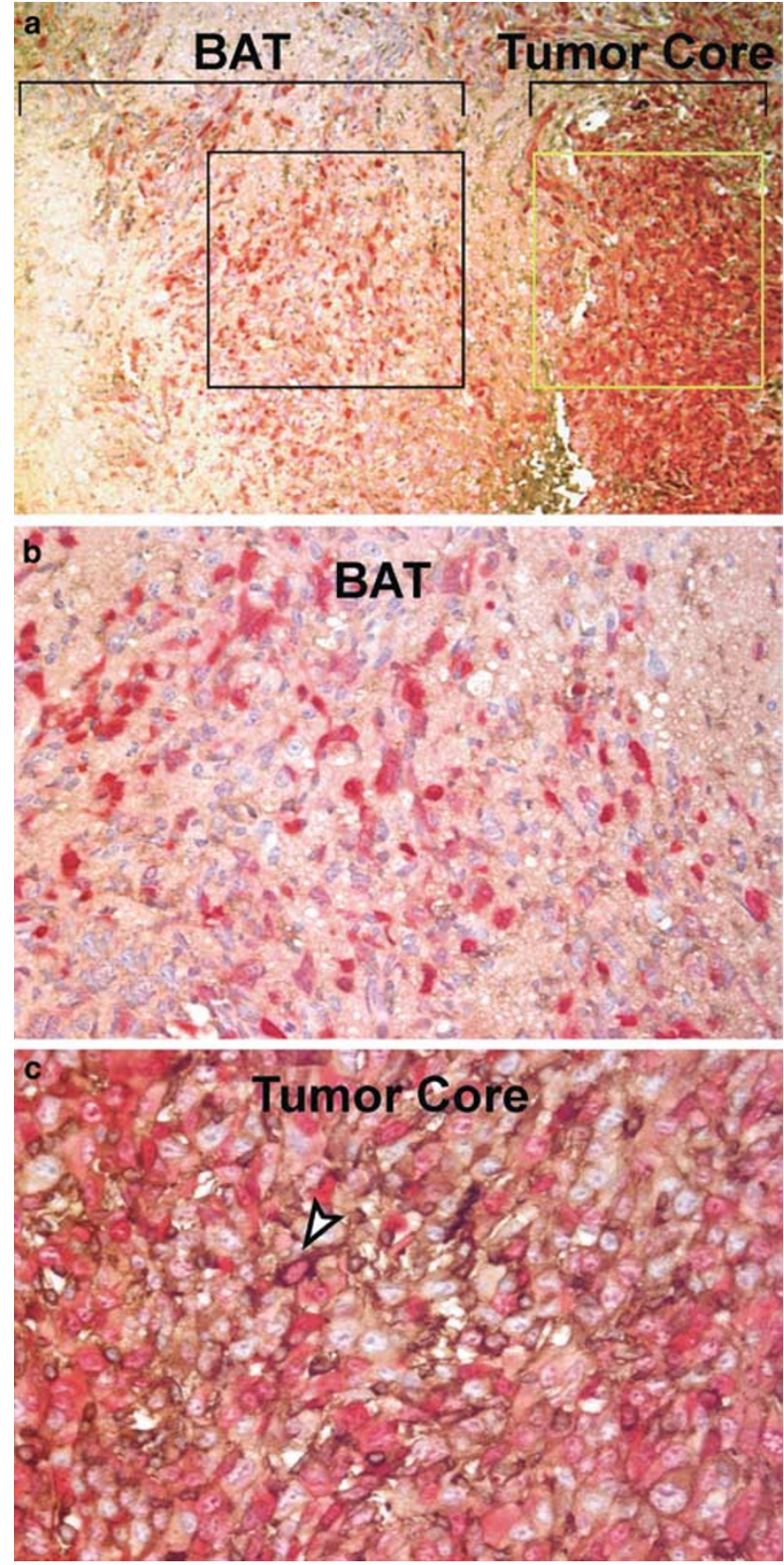

Figure 5 Downregulation of MHC class I expression at the invasive edge of murine GL261 glioma. (a) Low magnification showing GFP-tagged GL261 glioma cells infiltrating the BAT (black box) and the tumor core (yellow box); (original magnification $\times 40$ ); (b) The area depicted corresponds to a region within the BAT (black box in panel a). The BAT shows GFP labeledGL261 glioma cells immunostained with anti-GFP antibody (red) that lack immunoreactivity for $\beta 2$ microglobulin (brown); (original magnification $\times 400$ ); (c) The area depicted corresponds to a region within the tumor core (yellow box in panel a). The GFPtagged GL261 glioma cells (red) show abundant immunoreactivity for $\beta 2$ microglobulin (brown, arrowhead); (original magnification $\times 400)$.

must be presented by MHC molecules. Antigen presentation in the context of both MHC class I and II molecules is necessary for the development and maintenance of effective antitumor immunity.
Downregulation of MHC class I molecules is observed in many human tumors and transformed cell lines resulting in decreased susceptibility to cytotoxic T-cell-mediated lysis. ${ }^{59-63}$ Tumor antigenspecific CD8 + cytotoxic $\mathrm{T}$ cells recognize and destroy tumor cells carrying MHC class I antigens on their cell surface and are the main effectors against tumors in both human tumors and mouse models. ${ }^{64}$ On the other hand, CD4 + helper T cells recognize peptide antigens presented by MHC class II molecules. The observation that MHC class I-positive but not MHC class I-negative intracerebral tumor grafts in murine brain are rejected ${ }^{65}$ demonstrates the importance of MHC class I molecule expression. Results from our in vitro and in vivo studies suggest that migrating and invading glioma cells, respectively, suppress their antigenicity via downregulation of MHC expression. Thus, altered MHC expression probably constitutes one of the major escape mechanisms of glioma cells from antitumor T-cell mediated responses, that is, 'stealth invasion.'

The central nervous system (CNS) has been considered an immunologically privileged site $^{66}$ and shown to be a barrier to allograft and xenograft rejection. Although some studies have suggested that immunotherapy may not be effective against CNS tumors, ${ }^{67,68}$ recent work has shown that the CNS is routinely surveyed by cells of the immune system. ${ }^{69}$ Vaccination studies in animals showed that it is possible to stimulate a potent immune response against CNS tumors. ${ }^{70}$ Thus, the CNS may not be an immunological privileged site as once thought and may be susceptible to active immunotherapy. Our observation that MHC class I and II genes were downregulated in migrating and invading glioma cells may have important implications for the potential use of immunotherapies against GBMs. Recent studies, known as immunogene therapy, ${ }^{53}$ have focused on genetically modifying glioma cells to enhance their immunogenicity. For example, glioma cells engineered to express the IL12 cytokine promoted antitumor immunity. Thus, strategies either to prevent downregulation of MHC gene expression or induce its upregulation on invading glioma cells may increase their susceptibility to the antitumor T-cell-mediated immune response of the host.

In summary, we have observed that migration and invasion of glioma cells is associated with downregulation of MHC class I and II antigens. We propose that in the CNS, downregulation of MHC expression allows glioma tumor cells to invade the BAT undetected by the immune system. This could account, at least in part for the lack of inflammatory infiltrate around individual invading glioma cells. This 'stealth invasion' may be involved in the fundamental process that makes diffusely infiltrating GBMs extremely difficult to cure. Although classic immunotherapeutic approaches targeting malignant gliomas have yet to yield definitive 
therapy, a better understanding of how MHC antigen expression is controlled in invading glioma cells could have potential implications for the development of novel therapeutic approaches, for example, vaccine-based cancer therapeutics.

\section{Acknowledgements}

We thank Eugene Lukyanov and Greg Radin for their help in preparing the manuscript. This work was supported by a Grant from the National Institutes of Health (to DZ) R01 CA100426-01A1.

\section{References}

1 Silbergeld DL, Chicoine MR. Isolation and characterization of human malignant glioma cells from histologically normal brain. J Neurosurg 1997;86:525-531.

2 Eberhard A, Kahlert S, Goede V, et al. Heterogeneity of angiogenesis and blood vessel maturation in human tumors: implications for antiangiogenic tumor therapies. Cancer Res 2000;60:1388-1393.

3 Maher EA, Furnari FB, Bachoo RM, et al. Malignant glioma: genetics and biology of a grave matter. Genes Dev 2001;15:1311-1333.

4 Zagzag D, Shiff B, Jallo GI, et al. Tenascin-C promotes microvascular cell migration and phosphorylation of focal adhesion kinase. Cancer Res 2002;62:2660-2668.

5 Dahlquist KD, Salomonis N, Vranizan K, et al. GenMAPP, a new tool for viewing and analyzing microarray data on biological pathways. Nat Genet 2002; 1:19-20.

6 Kent WJ. BLAT-the BLAST-like alignment tool. Genome Res 2002;4:656-664.

7 Doniger SW, Salomonis N, Dahlquist KD, et al. MAPPFinder: using Gene Ontology and GenMAPP to create a global gene-expression profile from microarray data. Genome Biol 2003;4:R7.

8 Baggerly KA, Coombes KR, Hess KR, et al. Identifying differentially expressed genes in cDNA microarray experiments. J Comput Biol 2001;8:639-659.

9 El Rouby S, Thomas A, Costin D, et al. p53 gene mutation in B-cell chronic lymphocytic leukemia is associated with drug resistance and is independent of MDR1/MDR3 gene expression. Blood 1993;82: 3452-3459.

10 Zagzag D, Miller DC, Chiriboga L, et al. Green fluorescent protein immunohistochemistry as a novel experimental tool for the detection of glioma cell invasion in vivo. Brain Pathol 2003;13:34-37.

11 Redondo M, Garcia J, Villar E, et al. Major histocompatibility complex status in breast carcinogenesis and relationship to apoptosis. Hum Pathol 2003;34: 1283-1289.

12 Zagzag D, Amirnovin R, Greco MA, et al. Vascular apoptosis and involution in gliomas precede neovascularization: a novel concept for glioma growth and angiogenesis. Lab Invest 2000;80:837-849.

13 Galloway PG, Likavec MJ, Perry G. Tropomyosin isoform expression in normal and neoplastic astrocytes. Lab Invest 1990;62:163-170.
14 Businaro R, Fabrizi C, Fumagalli L, et al. Synthesis and secretion of alpha 2-macroglobulin by human glioma established cell lines. Exp Brain Res 1992;88:213-218.

15 Mohanam S, Chandrasekar N, Yanamandra N, et al. Modulation of invasive properties of human glioblastoma cells stably expressing amino-terminal fragment of urokinase-type plasminogen activator. Oncogene 2002;21:7824-7830.

16 Tran NL, McDonough WS, Donohue PJ, et al. The human Fn14 receptor gene is up-regulated in migrating glioma cells in vitro and overexpressed in advanced glial tumors. Am J Pathol 2003;162:1313-1321.

17 Kunapuli P, Kasyapa CS, Hawthorn L, et al. LGI1, a putative tumor metastasis suppressor gene, controls in vitro invasiveness and expression of matrix metalloproteinases in glioma cells through the ERK1/2 pathway. J Biol Chem 2004;279:23151-23157.

18 Camby I, Belot N, Lefranc F, et al. Galectin-1 modulates human glioblastoma cell migration into the brain through modifications to the actin cytoskeleton and levels of expression of small GTPases. J Neuropathol Exp Neurol 2002;61:585-596.

19 Gunnersen JM, Spirkoska V, Smith PE, et al. Growth and migration markers of rat C6 glioma cells identified by serial analysis of gene expression. Glia 2000;32:146-154.

20 Hecker TP, Grammer JR, Gillespie GY, et al. Focal adhesion kinase enhances signaling through the Shc/ extracellular signal-regulated kinase pathway in anaplastic astrocytoma tumor biopsy samples. Cancer Res 2002;62:2699-2707.

21 Wang $\mathrm{H}$, Wang $\mathrm{H}$, Shen $\mathrm{W}$, et al. Insulin-like growth factor binding protein 2 enhances glioblastoma invasion by activating invasion-enhancing genes. Cancer Res 2003;63:4315-4321.

22 Abounader R, Lal B, Luddy C, et al. In vivo targeting of $\mathrm{SF} / \mathrm{HGF}$ and c-met expression via U1snRNA/ribozymes inhibits glioma growth and angiogenesis and promotes apoptosis. FASEB J 2002;16:108-110.

23 Chicoine MR, Silbergeld DL. Mitogens as motogens. J Neurooncol 1997;35:249-257.

24 Dirks PB. Glioma migration: clues from the biology of neural progenitor cells and embryonic CNS cell migration. J Neurooncol 2001;53:203-212.

25 Nutt CL, Mani DR, Betensky RA, et al. Gene expression-based classification of malignant gliomas correlates better with survival than histological classification. Cancer Res 2003;63:1602-1607.

26 Gladson CL. The extracellular matrix of gliomas: modulation of cell function. J Neuropathol Exp Neurol 1999;58:1029-1040.

27 Uhm JH, Dooley NP, Kyritsis AP, et al. Vitronectin, a glioma-derived extracellular matrix protein, protects tumor cells from apoptotic death. Clin Cancer Res 1999;5:1587-1594.

28 Tatenhorst L, Senner V, Puttmann S, et al. Regulators of G-protein signaling 3 and 4 (RGS3, RGS4) are associated with glioma cell motility. J Neuropathol Exp Neurol 2004;63:210-222.

29 Ishiuchi S, Tsuzuki K, Yoshida Y, et al. Blockage of $\mathrm{Ca}(2+)$-permeable AMPA receptors suppresses migration and induces apoptosis in human glioblastoma cells. Nat Med 2002;8:971-978.

30 Perego C, Vanoni C, Massari S, et al. Invasive behaviour of glioblastoma cell lines is associated with altered organisation of the cadherin-catenin adhesion system. J Cell Sci 2002;115:3331-3340. 
31 Lampson LA, Hickey WF. Monoclonal antibody analysis of MHC expression in human brain biopsies: tissue ranging from 'histologically normal' to that showing different levels of glial tumor involvement. J Immunol 1986;136:4054-4062.

32 Munz C, Naumann U, Grimmel C, et al. TGF-betaindependent induction of immunogenicity by decorin gene transfer in human malignant glioma cells. Eur J Immunol 1999;29:1032-1040.

33 Fontana A, Hengartner $\mathrm{H}$, de Tribolet $\mathrm{N}$, et al. Glioblastoma cells release interleukin 1 and factors inhibiting interleukin 2-mediated effects. J Immunol 1984;132:1837-1844.

34 Siepl C, Bodmer S, Frei K, et al. The glioblastomaderived $\mathrm{T}$ cell suppressor factor/transforming growth factor-beta 2 inhibits $\mathrm{T}$ cell growth without affecting the interaction of interleukin 2 with its receptor. Eur J Immunol 1988;18:593-600.

35 Bodmer S, Strommer K, Frei K, et al. Immunosuppression and transforming growth factor-beta in glioblastoma. Preferential production of transforming growth factor-beta 2. J Immunol 1989;143:3222-3229.

36 Kuppner MC, Sawamura Y, Hamou MF, et al. Influence of PGE2- and cAMP-modulating agents on human glioblastoma cell killing by interleukin-2-activated lymphocytes. J Neurosurg 1990;72:619-625.

37 Wrann M, Bodmer S, de Martin R, et al. $\mathrm{T}$ cell suppressor factor from human glioblastoma cells is a 12.5-kd protein closely related to transforming growth factor-beta. EMBO J 1987;6:1633-1636.

38 Schneider J, Hofman FM, Apuzzo ML, et al. Cytokines and immunoregulatory molecules in malignant glial neoplasms. J Neurosurg 1992;77:265-273.

39 Van Meir E, Sawamura Y, Diserens AC, et al. Human glioblastoma cells release interleukin 6 in vivo and in vitro. Cancer Res 1990;50:6683-6688.

40 Nitta T, Hishii M, Sato K, et al. Selective expression of interleukin-10 gene within glioblastoma multiforme. Brain Res 1994;649:122-128.

41 Lichtor T, Libermann TA. Coexpression of interleukin1 beta and interleukin-6 in human brain tumors. Neurosurgery 1994;34:669-673.

42 Huettner C, Paulus W, Roggendorf W. Messenger RNA expression of the immunosuppressive cytokine IL-10 in human gliomas. Am J Pathol 1995;146:317-322.

43 Hishii $M$, Nitta $T$, Ishida $\mathrm{H}$, et al. Human gliomaderived interleukin-10 inhibits antitumor immune responses in vitro. Neurosurgery 1995;37:1160-1167.

44 Palma C, Manzini S. Substance P induces secretion of immunomodulatory cytokines by human astrocytoma cells. J Neuroimmunol 1998;81:127-137.

45 Parney IF, Farr-Jones MA, Chang LJ, et al. Human glioma immunobiology in vitro: implications for immunogene therapy. Neurosurgery 2000;46: 1169-1177.

46 Fontana A, Kristensen F, Dubs R, et al. Production of prostaglandin $\mathrm{E}$ and an interleukin-1 like factor by cultured astrocytes and C6 glioma cells. J Immunol 1982;129:2413-2419.

47 Kuppner MC, Hamou MF, Sawamura Y, et al. Inhibition of lymphocyte function by glioblastoma-derived transforming growth factor beta 2 . J Neurosurg 1989;71:211-217.

48 Sawamura Y, Diserens AC, de Tribolet N. In vitro prostaglandin E2 production by glioblastoma cells and its effect on interleukin-2 activation of oncolytic lymphocytes. J Neurooncol 1990;9:125-130.
49 Couldwell WT, Dore-Duffy P, Apuzzo ML, et al. Malignant glioma modulation of immune function: relative contribution of different soluble factors. J Neuroimmunol 1991;33:89-96.

50 Black KL, Chen K, Becker DP, et al. Inflammatory leukocytes associated with increased immunosuppression by glioblastoma. J Neurosurg 1992;77:120-126.

51 Dix AR, Brooks WH, Roszman TL, et al. Immune defects observed in patients with primary malignant brain tumors. J Neuroimmunol 1999;100:216-232.

52 Wagner S, Czub S, Greif M, et al. Microglia/macrophage expression of interleukin 10 in human glioblastomas. Int J Cancer 1999;82:12-16.

53 Mosmann TR, Sad S. The expanding universe of T-cell subsets: Th1, Th2 and more. Immunol Today 1996;17: 138-146.

54 Parney IF, Hao C, Petruk KC. Glioma immunology and immunotherapy. Neurosurgery 2000;46:778-791.

55 Garcia-Lora A, Algarra I, Garrido F. MHC class I antigens, immune surveillance, and tumor immune escape. J Cell Physiol 2003;195:346-355.

56 Facoetti A, Capelli E, Nano R. HLA class I molecules expression: evaluation of different immunocytochemical methods in malignant lesions. Anticancer Res 2001;21:2435-2440.

57 Tait BD. HLA class I expression on human cancer cells. Implications for effective immunotherapy. Hum Immunol 2000;61:158-165.

58 Algarra I, Cabrera T, Garrido F. The HLA crossroad in tumor immunology. Hum Immunol 2000;61:65-73.

59 Doyle A, Martin WJ, Funa K, et al. Markedly decreased expression of class I histocompatibility antigens, protein, and mRNA in human small-cell lung cancer. J Exp Med 1985;161:1135-1151.

60 Tanaka K, Isselbacher KJ, Khoury G, et al. Reversal of oncogenesis by the expression of a major histocompatibility complex class I gene. Science 1985;228:26-30.

61 Moller P, Herrmann B, Moldenhauer G, et al. Defective expression of MHC class I antigens is frequent in B-cell lymphomas of high-grade malignancy. Int J Cancer 1987;40:32-39.

62 Restifo NP, Kawakami Y, Marincola F, et al. Molecular mechanisms used by tumors to escape immune recognition: imunogenetherapy and the cell biology of major histocompatibility complex class I. J Immunother 1993;14:182-190.

63 Travers PJ, Arklie JL, Trowsdale J, et al. Lack of expression of HLA-ABC antigens in choriocarcinoma and other human tumor cell lines. Natl Cancer Inst Monogr 1982;60:175-180.

64 Melief CJ, Kast WM. Cytotoxic T lymphocyte therapy of cancer and tumor escape mechanisms. Semin Cancer Biol 1991;2:347-354.

65 Ljunggren HG, Yamasaki T, Collins P, et al. Selective acceptance of MHC class I-deficient tumor grafts in the brain. J Exp Med 1988;167:730-735.

66 Tjuvajev J, Gansbacher B, Desai R, et al. RG-2 glioma growth attenuation and severe brain edema caused by local production of interleukin-2 and interferon-gamma. Cancer Res 1995;55:1902-1910.

67 Schackert HK, Itaya T, Schackert G, et al. Systemic immunity against a murine colon tumor (CT-26) produced by immunization with syngeneic cells expressing a transfected viral gene product. Int J Cancer 1989;43:823-827.

68 Cassel WA, Weidenheim KM, Campbell Jr WG, et al. Malignant melanoma. Inflammatory mononuclear cell 
infiltrates in cerebral metastases during concurrent therapy with viral oncolysate. Cancer 1986;57: 1302-1312.

69 Hickey W. Basic principles of immunological surveillance of the normal central nervous system. Glia 2001;36:118-124.
70 Sampson JH, Archer GE, Ashley DM, et al. Subcutaneous vaccination with irradiated, cytokine-producing tumor cells stimulates CD8+ cell-mediated immunity against tumors located in the 'immunologically privileged' central nervous system. Proc Natl Acad Sci USA 1996;93:10399-10404. 